FOLIA SCANDINAVICA VOL. 25 POZNAŃ 2018 DOI: $10.2478 /$ fsp-2018-0011

\title{
SETNINGER I NORSK OG POLSK - DEFINISJONER OG INNDELINGER
}

\author{
MARTA OLGA JANIK* \\ OLIWIA SZYMAŃSKA ** \\ BARBARA ŁUKASZEWICZ ${ }^{* * *}$ \\ * SWPS University of Social Sciences and Humanities, Warsaw \\ ${ }^{* *}$ University of Oslo \\ ${ }^{* * *}$ University of Warsaw
}

ABSTRACT. In this article we give a brief summary of how Norwegian and Polish sentences are classified in the widely acknowledged grammar books. Therefore, we review the definitions of sentences in both languages, and compare the various classifications applied in Norwegian and Polish. Additionally, much focus is given to classification of sub clauses, which happen to be differently characterized in the respective languages. We would claim that there is a significant bias regarding features that determine classification of sub clauses in Norwegian and Polish. While in Norwegian a lot of emphasis is put on structural features, focusing on how particular units are organized within a sentence, the Polish classifications seem more semantic-oriented. As far as grammatical terms are concerned, Norwegian is featured by far more notions that might yield intransparency for a Polish learner or grammarian. On the other hand, the Norwegian classifications seem far more transparent. Due to a lack of 1-1 relation between terms used in Norwegian and Polish, we cater for this need by providing terms applicable for both languages. We believe that this may come into useful for all who try to systematize their knowledge about sentences in both languages.

\section{INNLEDNING}

Denne artikkelen tar for seg setningsproblematikken i norsk og polsk. Grunnet stadig flere kontrastive studier med norsk og polsk i fokus, mener vi at en bredere oversikt over måten disse systematiseres på i begge språkene, kunne være et godt utgangspunkt for videre studier. Det mangler nemlig fortsatt en relativt uttømmende sammenlikning av setninger i norsk og 
polsk av nyere dato. Den eneste vi har funnet er Skommer (1979). Derfor har vi et stort håp om at artikkelen bidrar til å fylle denne luken i noen grad. Den opprinnelige tanken bak artikkelen var å rette fokus kun mot leddsetninger, som grunnet sitt mangfold virket mest interessant. Under litteraturgjennomgangen ble det imidlertid tydelig at vi heller bør anvende en mer systematisk tilnærming der vi først introduserer selve setningsbegrepet og måten det behandles i de respektive to språkene. Vi går ut fra å presentere systematikken av ulike ytringer, for å videre rette fokuset mot ulike typer setninger. Deretter går vi inn på leddsetninger og presenterer veletablerte inndelinger, der disse ulike setningstypene presenteres med en god del eksempler i begge språkene. På denne måten mener vi oversikten blir mer ryddig og enklere å ta i bruk. Formålet med denne artikkelen er derfor todelt. For det første har vi i sikte å presentere de vanligste inndelinger av setninger og leddsetninger i begge språkene, for det andre viser vi inndelingene $i$ et kontrastivt perspektiv. Vi har stort håp om at artikkelen vil hjelpe å systematisere kunnskap om setninger og leddsetninger på et kontrastivt plan.

Polsk og norsk virker meget forskjellige når man tenker på setningsstruktur. På den ene side har vi polsk, et syntetisk språk som gir gode premisser for å stokke om på setningen slik at den forblir grammatisk, men får en litt annen betydning. På den andre har vi norsk, som er et langt mer analytisk språk med en heller rigid setningsstruktur, der en endring enten medfører betydningsnyansering eller gjør setningen ugrammatisk. Likevel finner vi ganske like ideer om selve setningsbegrepet og klassifisering av enkelte setningstyper. Flere grammatikkforskere, både polske og norske, har beskjeftiget seg med setningsproblematikken og har foreslått egne inndelinger. Noen av dem er veldig like, mens andre byr på mer komplekse klassifiseringsmønstre.

Av hensyn til at de norske inndelingene kjennetegnes av en større gjennomsiktighetsgrad, velger vi å omtale emnet fra norsk perspektiv, derfor presenteres den norske systematikken først (seksjon 2). Deretter (seksjon 3) skal vi kontrastere dem med polske inndelingsmønstre og avslutningsvis (seksjon 4) peke på likheter og ulikheter. Vi kommer også til å presentere en liste over setningsbegrepene som brukes i begge språkene. Den kan tas i bruk ved kontrastive studier.

\section{SETNINGER I NORSK}

Setningsbegrepet får mye oppmerksomhet og omtales nøye i flere norske grammatikkbøker. Beskrivelsene er i utgangspunktet teoriløse, men måten tilnærmingen vinkles på, varierer litt hos enkelte forfattere. Noen retter mer fokus på det strukturelle (Enger og Kristoffersen 2000, Faarlund mfl. 1997¹ Lie 2003,

${ }^{1}$ Norsk Referansegrammatikk som skal være teorinøytral, legger betydelig mer fokus på strukturen enn på semantikken i beskrivelsen av leddsetninger. 
Vassenden 1993, Vinje 1999, Åfarli og Sakshaug 2006), Hagen (1998, 2008) kombinerer det strukturelle med semantikken, mens andre konsentrerer seg mer om setningenes semantiske og pragmatiske innhold (Golden mfl. 2014, Kulbrandstad 2005, Mac Donald 1999). Vi skal nå prøve å presentere setninger i et bredere perspektiv, der de mest prominente inndelingene føyes inn i et felles bilde.

Selv om man finner en rekke definisjoner på en setning basert på både grammatiske og semantiske forutsetninger, og ikke minst pragmatikk, later det til at det i norsk finnes nesten identiske krav for at en gitt struktur kan omtales som en setning. SETNING defineres nemlig som en «språklig ytring som består av et verb i finitt form kombinert med et ledd av typen subjekt - pluss eventuelle andre ledd» (Kulbrandstad 2005:226). Hagen (2008:241) presiserer videre «at alle setninger har et finitt verb, er altså ikke en empirisk observasjon, men et aksiomatisk utgangspunkt for identifikasjon av setningen som grammatisk kategori, en ufravikelig del av setningsbegrepet». Derimot bruker Lie (2003) begrepet YTRING som er i stor grad i tråd med setningsdefinisjonen hos andre, han skriver nemlig følgende: «Den delen av tekst som står mellom to store skilletegn, kaller vi en ytring. Med store skilletegn mener vi punktum, utropstegn og spørsmålstegn» (Lie 2003:32). En nesten identisk definisjon finner vi hos Golden mfl. (2014), hvilket vi kommer tilbake til. Her er det viktig å påpeke at imperativsetninger er også en type setninger selv om de ikke inneholder subjektleddet, men de inneholder et finitt verbal (Kulbrandstad 2005:229).

I tillegg til setninger finnes det setningsekvivalenter. Faarlund mfl. (1997) skiller mellom ytring, setning og SETNINGSFRAGMENT som de definerer som «yttringar som ikkje oppfyller krava til ei setning» (ibid.:923). Lie (2003) deler dem videre i to grupper, nemlig SETNINGSEMNER og SETNINGSEKVIVALENTER. Hagen (2008) foreslår derimot en mer detaljert klassifisering av disse, som han omtaler som HOVEDSETNINGSEKVIVALENTER (Hagen 2008:236). Denne kategorien, uavhengig av øremerket, dekker altså behovet for en gruppe strukturer som ligger veldig nær den opprinnelige setningsdefinisjonen, men samtidig mangler enkelte trekk som gjør at de kan klassifiseres som sådan. I Tabell 1 følger eksempler på samtlige ytringstyper.

\begin{tabular}{ccc}
\hline SETNINGER & SETNINGSEKVIVALENTER & $\begin{array}{c}\text { SETNINGSFRAGMENTER } \\
\text { SOM SELVSTENDIG TEKST }\end{array}$ \\
\hline Jeg drømmer om å flytte. & Fine greier! & Pause \\
Ikke snakk til meg nå. & Så ekkelt! & Bruktbutikk \\
\hline
\end{tabular}

(Tabell 1) Inndeling av ytringer i norsk. 
HOVEDSETNING (HELSETNING hos Golden mfl. 2014, Enger og Kristoffersen 2000, Mac Donald 1999 og Vinje 1999) defineres som en selvstendig ytring eller enhet, altså en setning som representerer an autonom talehandling, og som selv ikke er ledd i en umiddelbart overordnet setning (Hagen 1998:241). Når det gjelder klassifisering av hovedsetninger, er det stor enighet om å dele dem etter tematisk innhold og beskjed setningene skal formidle. Golden mfl. (2014:141-142) skriver om fortellende, oppfordrende og spørresetninger, mens Hagen foreslår inndeling i fire grupper, nemlig indikativsetninger, imperativsetninger, optativsetninger og interrogativsetninger, noe som tilsvarer Kulbrandstad (2005) og Lie (2003) sin inndeling i fortellende, byde-, ønskeog spørresetninger. I FORTELLENDE (indikative) SETNINGER er det fokus på visse faktaforhold. Deres typiske funksjon er «å referere fakta, og derved «peke på» (= lat. indicare) et saksforhold» (Hagen 2008:243). Formålet med IMPERATIVSETNINGER (oppfordrende, bydesetninger) er å få noen til å gjøre noe, de uttrykker altså et påbud eller et ønske og verbet står i imperativform. OPTATIVSETNINGER (ønskesetninger) gjelder vanligvis forsteinete uttrykk eller talerens lite sannsynlige ønsker og er ofte følelsesladet. Disse utgjør følgelig en relativ lukket og marginal kategori (Åfarli og Sakshaug 2006:146). Den siste gruppen er SPØRRESETNINGER (interrogativsetninger), som gir uttrykk for noe taleren lurer på. Hagen påpeker at «i den type setning er hele setningens påstandsinnhold prinsipielt usikkert, ingen del av interrogativsetningen er underforstått» (Hagen 1998:247). Man skiller mellom ja/neispørsmål og åpne spørsmål som åpner for flere typer svar. I Tabell 2 følger eksempler på hovedsetninger.

\begin{tabular}{cccc}
\hline $\begin{array}{c}\text { Fortellende } \\
\text { SETning }\end{array}$ & IMPERAtivsetning & OPtativsetning & SPørResetning \\
\hline $\begin{array}{c}\text { Han pleier å } \\
\text { besøke Polen hvert } \\
\text { år. }\end{array}$ & $\begin{array}{c}\text { Prøv igjen! } \\
\text { Ikke snakk sånn til } \\
\text { meg! }\end{array}$ & $\begin{array}{c}\text { Leve kongen! } \\
\text { Koste hva det } \\
\text { koste vil! }\end{array}$ & $\begin{array}{c}\text { Blir du med på fest } \\
\text { i kveld? } \\
\text { Hva har du tenkt å } \\
\text { gjøre i morgen? }\end{array}$ \\
\hline
\end{tabular}

(Tabell 2) Oversikt over hovedsetningstyper med eksempler.

Den grammatiske strukturen på hovedsetningen og plassering av enkelte ledd henger tett sammen med setningens semantiske innhold. I Tabell 3 viser vi plassering av setningsledd på begynnelsen av de fire hovedsetningstypene fordi det er akkurat den første delen av setningen som skiller dem formelt (Lie 2003:33). 


\begin{tabular}{cccc}
\hline $\begin{array}{c}\text { ForTEllende } \\
\text { SETNING }\end{array}$ & IMPERATIVSETNING & OPTATIVSETNING & SPøRRESETNING \\
\hline $\begin{array}{c}\text { Forfelt (unntatt } \\
\text { spørreord) + finitt } \\
\text { verb }\end{array}$ & $\begin{array}{c}\text { Tomt forfelt + finitt } \\
\text { verb i imperativ }\end{array}$ & $\begin{array}{c}\text { Tomt forfelt + verb i } \\
\text { konjunktiv }\end{array}$ & $\begin{array}{c}\text { Ja/nei-spørsmål: } \\
\text { tomt forfelt + finitt } \\
\text { verb }\end{array}$ \\
& & $\begin{array}{c}\text { Apne spørsmål: } \\
\text { spørreord i forfeltet } \\
+ \text { finitt verb }\end{array}$ \\
\hline
\end{tabular}

(Tabell 3) Oversikt over hovedsetningstyper med fokus på de formelle skillene.

Setninger kan kombineres i større betydningsenheter som bindes ved bruk av konjunksjoner eller subjunksjoner. To likestilte setninger knyttes sammen ved hjelp av konjunksjon, noe som resulterer i to hovedsetninger med likevekt, en såkalt paratakse (sideordning). Dersom det finnes noen forhold som giør at den ene setningen er underordnet den andre, har vi med en hypotakse (underordning) å gjøre. Hypotakse betyr altså et forhold mellom en over- og leddsetning, der disse to kombineres ved hjelp av en subjunksjon.

Definisjonen av en leddsetning, nemlig et setningsledd med eget subjekt og verbal med en fast ordstilling, preges av stor enstemmighet blant norske grammatikkforskere. Hagen (2008:249) påpeker at «leddsetninger er setninger som skiller seg fra hovedsetninger ved sin syntaktiske funksjon». Strukturelt sett snakker man gjerne om oversetning og undersetning. OVERSETNING er en setning som har «en vis leddsetning som ledd uten intervenerende setningsknute imellom» (Hagen 1998:241)2. Egner og Kristoffersen (2005:268) definerer LEDDSETNING som «ei innføyd setning som står som eige setningsledd i ei setning». Det er vanlig at den type setning innledes med subjunksjon som markerer leddets underordnede stilling. Avhengig av type innhold og følgelig funksjon, deles leddsetninger i tre grupper, nemlig NOMINALE, ADVERBIALE og ADJEKTIVISKE. Disse tre hovedgruppene byr på flere undertyper, avhengig av hvordan enkelte grammatikkforskere definerer dem. En interessant dikotomi finner vi hos Faarlund mfl. (1997) som framhever et skille mellom EKSPLIKATIVE og IMPLIKATIVE leddsetninger, der inndelingen går inn mer på strukturelle trekk, men som egentlig tilsvarer den ovennevnte inndelingen i nominale, adverbiale og adjektiviske setninger. Videre skal vi redegjøre for de enkelte leddsetningstypene.

Nominale (substantiviske) leddsetninger fungerer omtrent identisk som andre nominale ledd, dvs. som subjekt, predikativ, objekt og ikke minst som en preposisjonsstyring ${ }^{3}$. Denne gruppen inkluderer også avhengige spørresetninger.

2 Setningsknute er et begrep som betegner et ledd plassert $i$ en overordnet setning (oversetning) selv om det logisk sett tilhører leddsetningen. På denne måten framheves leddet $\mathrm{i}$ setningen, f.eks. Blomster vet jeg en mann som selger på Stortorget.

${ }^{3}$ Hagen definerer preposisjonsstyring som «den referensielle konstituent som etterfølger preposisjonen» (1998:153). 


\begin{tabular}{|c|c|c|}
\hline $\begin{array}{l}\text { NOMINAL SETNING } \\
\text { SOM SUBJEKT }\end{array}$ & $\frac{\text { Om han er en flink lege, er }}{\text { et godt spørsmål. }}$ & $\frac{\text { At du sier noe slik }}{\text { sjokkerende for meg }}$ \\
\hline $\begin{array}{l}\text { NOMINAL SETNING } \\
\text { SOM PREDIKATIV }\end{array}$ & $\begin{array}{l}\begin{array}{l}\text { Årsaken til problemet er at } \\
\text { sjefen mobbet kontor- } \\
\text { assistenten. }\end{array}\end{array}$ & $\begin{array}{c}\text { Hemmeligheten bak } \\
\text { suksessen hans er at han er } \\
\text { åpen for nye løsninger. }\end{array}$ \\
\hline $\begin{array}{l}\text { NOMINAL SETNING } \\
\text { SOM OBJEKT }\end{array}$ & $\begin{array}{l}\text { Jeg vet ikke om jeg blir } \\
\text { ferdig med artikkelen før } \\
\underline{\text { innen 1. mars. }}\end{array}$ & $\begin{array}{l}\text { Kan dere endelig fortelle } \\
\text { oss hvor dere har tenkt å } \\
\text { gifte dere? }\end{array}$ \\
\hline $\begin{array}{l}\text { NOMINAL SETNING SOM } \\
\text { PREPOSISJONSSTYRING }\end{array}$ & $\begin{array}{l}\text { Han tviler på at hun } \\
\text { kommer i tide. }\end{array}$ & \\
\hline
\end{tabular}

(Tabell 4) Oversikt over nominale leddsetninger med eksempler.

Adverbiale leddsetninger fungerer som adverbialer og er derfor en meget omfattende gruppe der inndelingen hovedsakelig bygger på setningens semantiske innhold. I denne gruppen finner vi årsakssetninger, følgesetninger, hensiktssetninger, betingelsessetninger (vilkårssetninger), innrømmelsessetninger (motsetningssetninger), stedssetninger, tidssetninger og sammenlikningssetninger. Hver undertype innledes ved hjelp av en bestemt subjunksjon som antyder årsaksforholdet. Navn på de enkelte undertypene antyder deres funksjon, der årsakssetning oppgir grunnen til det som forekommer $\mathrm{i}$ resten av hovedsetningen, følgesetning omtaler resultatet av det som beskrives foran (Golden mfl. 2014:147), hensiktssetning definerer formålet med handlingen i resten av setningen, betingelsessetning forteller om krav som må oppfylles for at innholdet $\mathrm{i}$ hovedsetningen skal være aktuelt, i innrømmelsessetning er det forskjell mellom tankene leddsetningen retter oss mot, og innholdet i hovedsetningen, stedssetning oppgir sted hvor handlingen inntreffer, mens tidssetning definerer tidsrom for handlingen. I Tabell 5 presenterer vi eksempler på alle typer på adverbiale leddsetninger.

\begin{tabular}{|c|c|c|}
\hline ÅRSAKSSETNING & $\begin{array}{l}\text { Jeg kommer ikke i kveld } \\
\text { fordi jeg har masse å } \\
\text { gjøre. }\end{array}$ & $\begin{array}{l}\text { Da han ikke skrev } \\
\text { eksamen ferdig, fikk han } \\
\text { stryk med det samme. }\end{array}$ \\
\hline FølGESETNING & $\begin{array}{l}\text { Hun var så svak at hun } \\
\text { holdt på å besvime. }\end{array}$ & $\begin{array}{l}\text { Han fikk gnagsår slik at } \\
\text { de måtte ta en pause. }\end{array}$ \\
\hline HENSIKTSSETNING & $\begin{array}{l}\text { Jeg skal gjøre leksen nå } \\
\text { for at jeg skal ha fri på } \\
\text { ettermiddagen. }\end{array}$ & $\begin{array}{l}\text { Jeg skal kaste søppel så } \\
\text { det ikke lukter fælt på } \\
\underline{\text { kjøkkenet. }}\end{array}$ \\
\hline
\end{tabular}




\begin{tabular}{|c|c|c|}
\hline $\begin{array}{l}\text { BETINGELSESSETNING } \\
\text { (VILKÅRSSETNING) }\end{array}$ & $\frac{\text { Hvis du hjelper meg nå }}{\text { får du se fotballkampen. }}$ & $\begin{array}{l}\text { Jeg kan godt stikke innom } \\
\text { dersom du har lyst til å se } \\
\underline{\text { meg. }}\end{array}$ \\
\hline INNRØMMELSESSETNING & $\begin{array}{l}\text { Selv om jeg ikke er helt } \\
\text { ferdig med prosjektet, ser } \\
\text { det veldig lovende ut. }\end{array}$ & $\begin{array}{l}\text { Han syklet som bare det } \\
\text { enda bakken var veldig } \\
\text { bratt. }\end{array}$ \\
\hline STEDSSETNING & Dra hvor du vil. & $\frac{\text { Her (som) vi bor nå, }}{\text { trives vi veldig godt. }}$ \\
\hline Tidssetning & $\frac{\text { Når jeg fullfører dette, }}{\text { blir jeg klar for ferie. }}$ & $\begin{array}{l}\text { Jeg bruker å høre på } \\
\text { lydbøker mens jeg kjører } \\
\text { til jobb. }\end{array}$ \\
\hline SAMMENLIKNINGSSETNING & $\begin{array}{l}\text { Hun er ikke så slank som } \\
\text { hun var i fjor. }\end{array}$ & $\begin{array}{l}\text { Han er faktisk sprekere } \\
\text { enn jeg trodde. }\end{array}$ \\
\hline
\end{tabular}

(Tabell 5) Oversikt over adverbiale leddsetninger med eksempler.

Adjektiviske setninger, ellers kalt for relative setninger, deles videre inn $\mathrm{i}$ RESTRIKTIVE og APPOSITIVE relativsetninger avhengig av sitt semantiske innhold. Mens restriktive setninger utgjør en del av substantivfrasen, blir appositive relativsetninger brukt som sidebemerkning, slik at tilhøreren ikke nødvendigvis identifiserer referenten (Hagen 2008:252). Egner og Kristoffersen (2005:268) påpeker at relativsetning er «den vanlegaste type utfyllingssetning».

\begin{tabular}{ll}
\hline \multicolumn{1}{c}{ RESTRIKTIV } & \multicolumn{1}{c}{ APPOsITIV } \\
\hline $\begin{array}{l}\text { Legen som undersøkte meg i går, } \\
\text { kommer fra Tsjekkia. }\end{array}$ & $\begin{array}{l}\text { Et rikt liv, som mange drømmer om, har } \\
\text { også sine mørke sider. }\end{array}$ \\
$\begin{array}{l}\text { En god ferie på stranda er det jeg har } \\
\text { mest lyst på. }\end{array}$ & $\begin{array}{l}\text { Jon, som du har møtt på festen, gifter seg } \\
\text { med Anne i juni. }\end{array}$ \\
\hline
\end{tabular}

(Tabell 6) Oversikt over adjektiviske setninger med eksempler - restriktive og appositive.

I tillegg til den ovennevnte inndelingen foreslår Kulbrandstad (2005) et begrep LEDD-DELSETNINGER, det vil si setninger som ikke utgjør egne ledd, men inngår som deler av ledd i andre setninger (2005:226) og Golden mfl. (2014) skiller ut strukturer som presentering og utbrytning uten å putte dem i noen av de ovennevnte kategoriene, men framhever heller deres funksjon i ytringen. Hos Eger og Kristoffersen (2005) er det derimot snakk om utfyllingssetninger som er «ei innføyd setning som står som utfylling til hovudet i ein frase» (ibid.:268). 
Norske setninger beskrives altså ofte med mye fokus på sitt grammatiske innhold. Nærværet av leddsetninger innebærer vise endringer på setningens strukturelle plan, det vil si inversjon ${ }^{4}$ i hovedsetning og restriktiv plassering av de fleste setningsadverbialer dersom leddsetningen er foranstilt. Plassering av setningsadverbialer i leddsetninger er også verdt en nærmere analyse, spesielt i et kontrastivt perspektiv.

\section{SETNINGER I POLSK}

Inndelingen av YTRINGER (wypowiedzenia) i polsk er stort sett lik den som gjelder norske ytringer. Den mest utbredte er innført av Klemensiewicz (1963:5-7), og henviser ikke (likt de fleste norske) til en bestemt lingvistisk teori. Klemensiewicz' klassifisering bygger stort sett på tilstedeværelse eller fravær av et finitt verbal. Hvis en ytring inneholder et finitt verb, kalles den for en SETNING (zdanie), hvis ikke - er det snakk om SETNINGSEKVIVALENTER (oznajmienia). Disse to hovedtypene ble supplert av Pisarek (1964) med SETNINGSFRAGMENTER SOM SELVSTENDIG TEKST (zawiadomienia). Den sistnevnte gruppen kan hovedsakelig sees på skilt eller etiketter. Tabell 7 viser eksempler på ulike typer ytringer i polsk.

\begin{tabular}{ccc}
\hline SETNINGER & SETNINGSEKVIVALENTER & $\begin{array}{c}\text { SETNINGSFRAGMENTER } \\
\text { SOM SELVSTENDIG } \\
\text { TEKST }\end{array}$ \\
\hline $\begin{array}{c}\text { Odpoczywam. (Jeg hviler } \\
\text { ut.) }\end{array}$ & $\begin{array}{c}\text { Coś strasznego. } \\
\text { forferdelig!) }\end{array}$ & Mleko (Melk) \\
\hline $\begin{array}{c}\text { Nie jedz tego. (Ikke spis } \\
\text { det.) }\end{array}$ & $\begin{array}{c}\text { To niestychane! (Noe } \\
\text { uhørt!) }\end{array}$ & $\begin{array}{c}\text { Salon fryzjerski } \\
\text { (Frisørsalong) }\end{array}$ \\
\hline
\end{tabular}

(Tabell 7) Inndelingen av ytringer i polsk

Det er vanlig å dele setningene videre, avhengig av antallet finitte verbaler de inneholder. Klemensiewicz (1963:8) deler setninger i ENKLE YTRINGER ${ }^{6}$ (wypowiedzenia pojedyncze), DOBBELT SAMMENSATTE YTINGER (wypowiedzenia złożone dwukrotnie) og FLERSAMMENSATTE YTRINGER (wypowiedzenia złożone wielokrotnie), alt etter om de inneholder ett, to eller flere finitte verbaler. Likevel er det vanligere (bl.a. i Bąk 2016 og Wróbel 2001) å ta i bruk en todeling

\footnotetext{
${ }^{4}$ Inversjon defineres som en type leddstilling som oppstår «når et annet ledd enn subjektet står i forfeltet» (Klubrandstad 2005:266). I slike tilfeller «kommer subjektet rett etter det finitte verbalet i midtfeltet (altså på n-plassen)» (ibid.).

${ }^{5}$ Eksemplet hentet fra Klemensiewicz (1963:7).

${ }^{6}$ Han bruker begrepet ytring (wypowiedzenie) selv om han mener bare de ytringene som inneholder minst ett finitt verbal, dvs. setninger.
} 
der setninger deles i enkle (hvis de inneholder ett finitt verbal) og sammensatte (hvis de inneholder flere enn ett verbal), mens Polański (1978:9) definerer sammensatte setninger som setninger med to eller flere enkle setninger som utgjør en helhet. En ENKEL SETNING karakteriseres av ett verbal, mens SAMMENSATTE SETNINGER må inneholde to eller flere verbaler. Wróbel (2001) nevner i sin tur DELSETNINGER (zdania skladowe) som danner en sammensatt setning. De tilsvarer setninger som er selvstendige når det gjelder strukturen (Wróbel 2001:235).

Akkurat som i norsk klassifiseres polske setninger etter den pragmatiske rollen de spiller i diskursen. I den polske lingvistikken er det vanlig å kalle klassifiseringen for modal. Man snakker da om syntaktisk modalitet fordi setningen gir opplysninger om avsenders forhold til temaet som blir problematisert (Grzegorczykowa 2008:39). På dette grunnlaget deles setningene inn i FORTELLENDE SETNINGER ${ }^{7}$ (powiadomienia), SPØRSMÅL (pytania/interrogatywa), BEFALINGER (rozkazy/imperatywa) samt EKSPRESSIVE SETNINGER (ekspresywa). Tabell 8 viser eksempler på de ulike typene setninger.

\begin{tabular}{cccc}
\hline $\begin{array}{c}\text { FORTELLENDE } \\
\text { SETNINGER }\end{array}$ & SPØRSMÅL & BEFALINGER & $\begin{array}{c}\text { EKSPRESSIVE } \\
\text { SETNINGER }\end{array}$ \\
\hline $\begin{array}{c}\text { Jan } \text { wrócit. }^{8} \text { (Jan } \\
\text { har kommet } \\
\text { tilbake.) }\end{array}$ & $\begin{array}{c}\text { Czy Jan wrócit? } \\
\text { (Har Jan kommet } \\
\text { tilbake?) }\end{array}$ & $\begin{array}{c}\text { Janie, wróć! (Jan, } \\
\text { kom tilbake!) }\end{array}$ & $\begin{array}{c}\text { Jakie to piękne! } \\
\text { (Det er så } \\
\text { vakkert!) }\end{array}$ \\
\hline $\begin{array}{c}\text { Jan chyba } \text { wrócił. } \\
\text { (Jan har nok }\end{array}$ & $\begin{array}{c}\text { Kiedy Jan } \\
\text { wrócit? (Når kom } \\
\text { kommet tilbake.) }\end{array}$ & & \\
\hline
\end{tabular}

(Tabell 8) Inndelingen av setninger etter deres modalitet i polsk etter Grzegorczykowa (2008)

I polsk, slik som i norsk, er det vanlig å dele sammensatte setninger i to grupper: PARATAKTISKE (sideordnede) og HYPOTAKTISKE (underordnede). Paratakse er en relasjon mellom to hovedsetninger, mens hypotakse er en relasjon mellom en over- og leddsetning (Grzegorczykowa 2008:87). I hver av typene brukes det spesifikke bindeord som i teorien differensierer parataksen og hypotaksen, men som i praksis ofte brukes om hverandre. Grzegorczykowa (2008:99-100) innfører dessuten en annen inndeling av sammensatte setninger: setninger som er konnotert av verbalet (intensjonal- og objektsetninger), relativsetninger som har nominalgruppe som korrelat, og setninger som er forbundet

${ }^{7}$ Grzegorczykowa (ibid.) skriver ikke om setninger, men om ytringer generelt (noe som også inkluderer setninger). Fordi artikkelen ikke dreier seg om ytringer generelt, men om setninger, vil vi begrense oss til kun setninger der det er mulig.

${ }^{8}$ Eksemplene er hentet fra Grzegorczykowa (ibid.).

${ }^{9}$ Det er en verballøs ytring, og ikke en setning. 
på basis av semantikken, og som deles videre inn i parataktiske og hypotaktiske. I denne artikkelen vil vi imidlertid holde oss til den første, enklere inndelingen ettersom den ligner mer på den norske. Av samme grunn vil vi konsentrere oss om kun underordnede setninger her selv om både side- og underordnede setninger er grundig omtalt i polske grammatikker. Når det gjelder hypotaktiske setninger, er to klassifikasjoner generelt betraktet som de viktigste, nemlig de i Klemensiewicz (1963) og Polański (1967), og dem vil vi presentere nedenfor.

Ifølge Klemensiewicz deles leddsetninger etter hvilken del av helsetningen de supplerer eller erstatter: subjektet, attributtet, predikativet, adverbialet eller objektet. SUBJEKT- OG OBJEKTSETNINGER oppgir mer spesifiserende opplysninger om henholdsvis subjektet og objektet, PREDIKATIVSETNINGER erstatter en del eller hele predikativet, ATTRIBUTTSETNINGER spiller den samme rollen som attributter i setningen, og ADVERBIALSETNINGER deles videre inn i semantiske undertyper, avhengig av hvilket adverbial de erstatter. Det er et stort mangfold av den sistnevnte typen leddsetninger, og Klemensiewicz (1963:49-54) utpeker ti grupper adverbialsetninger ${ }^{10}$ : tidsadverbialytringer, stedsadverbialytringer, måtesadverbialytringer, gradsadverbialytringer, hensiktsadverbialytringer, årsaksadverbialytringer, godkjennelsesadverbialytringer, betingelsesadverbialytringer, resultatadverbialytringer og motsetningsadverbialytringer. Tabell 9 viser Klemensiewicz' klassifisering med eksempler.

\begin{tabular}{|c|c|c|}
\hline TYPE LEDDSETNING & EKSEMPEL & OVERSETTELSE \\
\hline SUBJEKTSETNING & $\begin{array}{l}\text { To, że pada, jest } \\
\text { przygnębiające. }\end{array}$ & $\begin{array}{l}\text { Det at det regner, er } \\
\text { deprimerende. }\end{array}$ \\
\hline ATTRIBUTTSETNING & $\begin{array}{c}\text { Widzę kobietę, która } \\
\text { odniosła sukces. }\end{array}$ & $\begin{array}{l}\text { Jeg ser en dame som har } \\
\text { oppnådd suksess. }\end{array}$ \\
\hline PREDIKATIVSETNING $^{11}$ & $\begin{array}{c}\text { Jan jest tym, którego } \\
\text { kocham. }\end{array}$ & Jan er den jeg elsker. \\
\hline ADVERBIALSETNING $^{12}$ & $\begin{array}{c}\text { Kupię dom, kiedy beedę } \\
\text { bogata. }\end{array}$ & $\begin{array}{l}\text { Jeg vil kjøpe hus når jeg } \\
\text { blir rik. }\end{array}$ \\
\hline OBJEKTSETNING & $\begin{array}{l}\text { Wiem, że nie mogę } \\
\text { dłużej czekać. }\end{array}$ & $\begin{array}{c}\text { Jeg vet at jeg ikke kan } \\
\text { vente lenger. }\end{array}$ \\
\hline
\end{tabular}

(Tabell 9) Klassifisering av leddsetninger etter Klemensiewicz (1963)

Grzegorczykowa (2008:96) hevder at Klemensiewicz' inndeling av leddsetninger har to store ulemper. For det første splitter han typer som egentlig er identiske (f.eks. subjekt- og objektsetninger). For det andre kombinerer han flere

${ }^{10}$ Han selv bruker begrepet «ytring» istedenfor «setning».

${ }^{11}$ Predikativsetningene Klemensiewicz oppgir, er egentlig ledd-delsetninger.

${ }^{12}$ De ulike typene adverbialsetninger ligner i største grad på norske adverbialsetninger, og derfor blir spesifikke eksempler ikke oppgitt. 
forskjellige typer setninger, f.eks. definerer han subjektsetninger gjennom eksempler på relativsetninger.

Polańskis (1967) klassifisering av leddsetninger ble videreutviklet av Bauer og Grepl (1970) og Daneš mfl. (1987), og den bygger på generativ grammatikk. Her deles leddsetninger inn i tre undergrupper: INTENSJONALE SETNINGER, RELATIVSETNINGER og ADVERBIALSETNINGER. Wróbel (2001:278) betegner intensjonale setninger som KONNOTERENDE SETNINGER, og de to resterende typene - IKKE-KONNOTERENDE. Tabell 10 presenterer eksempler på leddsetningstyper etter Polańskis (1967) klassifikasjon.

TYPE LEDDSETNING

INTENSJONAL SETNING ${ }^{13}$

RELATIVSETNING

ADVERBIALSETNING
EKSEMPEL

Czuję, że damy radę.
OVERSETTELSE

Jeg føler at vi greier det.

\begin{tabular}{|c|c|}
\hline $\begin{array}{l}\text { Maria, która właśnie } \\
\text { wróciła z Paryża, nie } \\
\text { może spać. }\end{array}$ & $\begin{array}{l}\text { Maria, som nettopp har } \\
\text { kommet tilbake fra Paris, } \\
\text { får ikke sove. }\end{array}$ \\
\hline $\begin{array}{l}\text { 3rałam prysznic, kiedy } \\
\text { dzwoniłeś. }\end{array}$ & dusjet da du ringte. \\
\hline
\end{tabular}

(Tabell 10) Klassifisering av leddsetninger etter Polański (1967)

Intensjonale setninger er styrt av verbet $\mathrm{i}$ oversetningen, og dette verbet tilhører en viss semantisk type (bl.a. mentale og perseptuelle) som krever supplering i form av uttrykk for tanke, vilje, følelse osv. Supplering kan angis som en leddsetning eller som et verbalsubstantiv. Det er cirka to tusen verb som framkaller intensjonalsetninger, og de kan slås opp i ordbøker ${ }^{14}$. Et eksempel på et intensjonalt verb er ŻĄDAĆ (kreve). Markowski (2004:521) beskriver verbets syntaktiske krav: «noen krever noe (+genitiv) - fra noen eller noe (+genitiv)»:

(1) Prokurator zażądał przedstawienia dowodów. Aktoren krevde at det forelegges bevis.

Grzegorczykowa (2008:112) legger merke til problemet som bruken av tempus $\mathrm{i}$ intensjonale setninger skaper, noe som hun illustrerer ved hjelp av eksemplet:

(2) Jan wie (dziwi się), że ojciec a) przyjedzie, b) przyjeżdża, c) przyjechał. Jan vet (undrer seg over) at faren a) skal komme, b) kommer, c) har kommet / kom.

${ }^{13}$ Polański (1967) bruker det semantikk-orienterte begrepet «intensjonale setninger» som i en syntaktisk orientert tilnærming kalles «objektsetninger».

${ }^{14}$ De to viktigste verkene er: Wielki stownik poprawnej polszczyny (Den store ordboken av korrekt polsk) av Markowski (2004) og Praktyczny stownik łaczliwości składniowej czasowników polskich (Praktisk ordbok av syntaktiske forbindelser i polske verb) av Mędak (2016). 
Jans viten (undring) er relatert til utsagnsøyeblikket, mens hendelsen referert til i den intensjonale setningen er relatert til Jans viten (undring). Forskjellen mellom relativ og spesifikk tid er ikke synlig dersom verbet i oversetningen står i presens (eksempel 2), men når verbet i oversetningen står i fortidsform (eksempel 3) eller futurum (eksempel 4), kommer det til en splittelse i handlingstiden i over- og leddsetningen, noe som ligner på tempusforskyving i norsk.

(3) Jan wiedział (dziwił się), że ojciec a) przyjedzie, b) przyjeżdża, c) przyjechał. Jan visste (undret seg over) at faren a) skulle komme, b) kom, c) hadde kommet.

(4) Jan dowie się (zdziwi się), że ojciec a) przyjedzie, b) przyjeżdża, c) przyjechał. Jan kommer til å vite (undre seg over) at faren a) skal komme, b) kommer, c) har kommet / kom.

Tempusspørsmålet er kanskje ikke problematisk fra et norsk perspektiv der man har både deiktiske og ikke-deiktiske tempusformer ${ }^{15}$, men det er et forholdsvis sjeldent fenomen i polsk hvor det bare finnes deiktiske tempusformer (Janik 2014:121). Tempusbruken i intensjonale setninger kunne være interessant å utforske, særlig kontrastivt med norsk tempusforskyving, noe det ikke er plass til i denne artikkelen.

En annen type leddsetninger utpekt av Polański (1967) er relativsetninger som modifiserer en nominalgruppe i oversetningen (ifølge Klemensiewicz' klassifikasjon er det subjekt-, objekt- og stedsadverbialsetninger). Grzegorczykowa (2008:118) deler relativsetninger i tre grupper: APPOSITIVE (også kalt determinerende), RESTRIKTIVE (også kalt begrensende) og UTVIKLENDE (tilsynelatende relative). Begrepene appositiv og restriktiv brukes i polsk på samme måte som i norsk (jf. Grzegorczykowa 2008:118-119 og Hagen 2008:252). Når det gjelder den siste typen, informerer de om en totalt ny hendelse som har inntruffet senere enn hendelsen beskrevet i oversetningen. En slik setning (eksempel 5) er bare tilsynelatende relativ (formelt relativ) fordi den ikke karakteriserer eller determinerer substantivet den er forbundet med, men informerer om en etterkommende hendelse, som ellers kan formidles ved hjelp av en sideordnet setning (eksempel 6):

(5) Weszli do pokoju, w którym dopiero rozpoczęto rozmowę.

De gikk inn på rommet hvor de først begynte å samtale.

(6) Weszli do pokoju i tam rozpoczęto rozmowę.

De gikk inn på rommet, og først da begynte de å samtale.

${ }^{15}$ En deiktisk tempusform trenger utsagnsøyeblikket som referansepunkt, mens en ikkedeiktisk tempusform kan ha et annet referansepunkt enn utsagnsøyeblikket (Bhat 1999). 
Den siste typen leddsetninger omtalt av Polański (1967) er adverbialsetninger (også kalt ekstensjonale setninger). De relaterer hendelser, handlinger og tilstander på basis av betydningsinnholdet i delsetningene. Slik som i Klemensiewicz (1963:88-98) er det snakk om et mangfold av ulike semantiske relasjoner. En stor og viktig gruppe adverbialsetninger utgjør temporale setninger $^{16}$, og dem vil vi se nøyere på. Grzegorczykowa (2008:124) utpeker to hovedtyper tidssetninger: DEIKTISKE og DURATIVE (også kalt fasesetninger). Den første gruppen leddsetninger plasserer hendelser i tid, mens den andre uttrykker hendelsens varighet. Hver av typene kan i tillegg deles etter tidsrelasjonen de har med oversetningen (det er snakk om samtidighet, førtidighet, og ettertidighet). Tabell 11 viser de ulike relasjonene nevnt ovenfor.

\begin{tabular}{|c|c|c|c|}
\hline $\begin{array}{l}\text { TYPE TEMPORAL } \\
\text { LEDDSETNING }\end{array}$ & $\begin{array}{l}\text { TIDSFORHOLD TIL } \\
\text { OVERSETNINGEN }\end{array}$ & EKSEMPEL & OVERSETTELSE \\
\hline \multirow{3}{*}{ DEIKTISK } & samtidighet & $\begin{array}{c}\frac{\text { Kiedy padał }}{\text { deszcz, }} \\
\text { siedzieliśmy } \\
\text { (całymi dniami) w } \\
\text { domu. }\end{array}$ & $\begin{array}{c}\text { Når det regnet, sat } \\
\text { vi (hele dager) } \\
\text { hjemme. }\end{array}$ \\
\hline & førtidighet & $\begin{array}{c}\text { Ledwie burza się } \\
\text { skończyła } \\
\text { wybiegli do } \\
\text { ogrodu. }\end{array}$ & $\begin{array}{c}\underline{\text { Så snart }} \\
\text { tordenværet var } \\
\underline{\text { slutt, løp de ut i }} \\
\text { hagen. }\end{array}$ \\
\hline & ettertidighet & $\frac{\text { Zanim wszed1 }}{\text { zastukał. }}$ & $\begin{array}{c}\frac{\text { Før han gikk inn }}{\text { banket han på }} \\
\text { døra. }\end{array}$ \\
\hline \multirow{3}{*}{ DURATIV } & samtidighet & $\begin{array}{l}\frac{\text { Dopóki był w }}{\text { domu, czuł się }} \\
\text { dobrze. }\end{array}$ & $\begin{array}{l}\frac{\text { Så lenge han var }}{\text { hjemme, følte han }} \\
\text { seg bra. }\end{array}$ \\
\hline & førtidighet & $\frac{\text { Odkad wyjechał (z }}{\frac{\text { domu), czuł się }}{\text { gorzej. }}}$ & 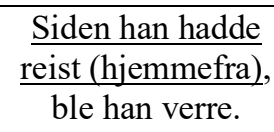 \\
\hline & ettertidighet & $\begin{array}{l}\text { Pracował nad tym, } \\
\text { aż osiagną̧ cel. }\end{array}$ & $\begin{array}{l}\text { Han hadde } \\
\text { arbeidet på det til } \\
\frac{\text { han oppnådde }}{\text { målet. }}\end{array}$ \\
\hline
\end{tabular}

(Tabell 11) Typer temporale setninger etter Grzegorczykowa (2008), eksemplene hentet derfra.

${ }^{16}$ De andre adverbialsetningene, så systematisk listet opp av Klemensiewicz (1963), legger Grzegorczykowa (2008) i samme gruppe - setninger som uttrykker årsak-følgeforhold. 
Veldig lite er skrevet om ordstillingen i polske leddsetninger. Wróbel (2001:299-300) nevner hvordan en helsetning er bygget opp: «Setning 1 Subjunksjon - Setning 2», og at subjunksjonen noen ganger kan utelates. Przybycin (1976) bestemmer leddsetningens plassering i helsetningen, og never fire muligheter: anteposisjon (foran i helsetningen), postposisjon (bak), interposisjon (i midten) og sirkumposisjon (omsluttende). De to første er de mest frekvente (forekommer i ca. 80 \% tilfeller), påstår hun. Det finnes imidlertid ikke noen presise regler for ordstilling som er forbundet med typologi og karakteristikk av polsk. Det er et bøyningsspråk (ikke analytisk språk), og dette medfølger en allmenn mening hos polskforskere om at det er lite behov for å vektlegge ordstillingen i leddsetninger, noe som er vesentlig i norsk.

\section{KARTLEGGING AV LIKHETER OG FORSKJELLER}

I de to forrige delene viste vi hvordan setninger er definert og klassifisert $\mathrm{i}$ norsk og polsk. I denne seksjonen vil vi sammenligne definisjonene og inndelingene ved å rette fokus mot likheter og forskjeller mellom språkene.

Det første som er felles i norsk og polsk i setningsområdet, er selve setningsdefinisjonen. Uavhengig av språk omtales setningen som en ytring som inneholder minst ett verb i finitt form (Hagen 2008, Klemensiewicz 1963, Kulbrandstad 2005). Dette er et viktig poeng ettersom det forsikrer at vi problematiserer nøyaktig det samme fenomenet i videre analyser.

Utover dette finner vi to felles trekk som gjelder inndeling av setninger. Både i norsk og polsk deler man setninger stort sett i fortellende setninger, spørsmål og befalinger (Golden mfl. 2014, Grzegorczykowa 2008, Hagen 2008). I tilfellet norsk nevner man likevel også optativsetninger (Hagen op.cit.), og i tilfellet polsk - ekspressive setninger (Grzegorczykowa op.cit.). Det at ekspressive setninger ikke blir skilt ut som separate grupper i den norske inndelingen, og optativsetninger i den polske, betyr imidlertid ikke at disse typene setninger er umulige i disse språkene. Når det gjelder ekspressive setninger i norsk (f.eks. Så dyrt det var!), er de vanligvis klassifisert som indikativsetninger. Optativsetninger (f.eks. Niech żyje król! [Leve kongen!]), er i sin tur en del av imperativsetninger i polsk. Den pragmatiske inndelingen av setningene er generelt lik i norsk og polsk, men det finnes noen nyanseforskjeller der.

Det siste trekket som er felles i setningsspørsmålet i norsk og polsk, gjelder klassifisering av sammensatte setninger. Riktignok er dette problematisert bare i polske grammatikker - sammensatte setninger inneholder flere enn ett finitt verb og de deles inn i sideordnede og de som inneholder en underordnet setning (Klemensiewicz 1963:8, Polański 1978:9), men de finnes også i norsk. Hver av gruppene karakteriseres med sitt eget sett bindeord. Vel å merke her at det $\mathrm{i}$ norsk finnes to typer bindeord: konjunksjoner (bindeord i parataktiske setninger) og subjunksjoner (bindeord i hypotaktiske setninger), og hver utgjør 
en egen ordklasse (Faarlund mfl. 1997) ${ }^{17}$, mens polsk byr på kun én ordklasse med bindeord (spójniki) som deles i to undertyper: sideordnede og underordnede bindeord (spójniki wspótrzędności i podrzędności).

En viktig forskjell mellom norsk og polsk som kan virke forvirrende i analysen, er at det i norsk finnes langt flere begreper som betegner en eller annen type setning: setning, helsetning, hovedsetning, oversetning, leddsetning og ledd-delsetning, mens det i polsk bare finnes fire setningsbegreper: zdanie, zdanie wspótrzędne, zdanie nadrzędne, zdanie podrzędne. Det mangler et én-tilén-forhold mellom disse begrepene. Vi er riktignok innforstått med at noen av de norske begrepene er foreldet og at de skyldes historisk utvikling $\mathrm{i}$ terminologien, men likevel er de brukt i de ulike grammatikkene, noe som fører til en viss forvirring. Derfor presenterer vi en sammenligning av setningsbegrepene i norsk og polsk. Noen av disse er veletablert, mens andre har vi utviklet selv med tanke på å fylle mangler i det norske leksikonet. Oversikten presenteres i Tabell 12.

\begin{tabular}{|c|c|c|c|}
\hline \multicolumn{2}{|c|}{ NORSK } & \multicolumn{2}{|c|}{ POLSK } \\
\hline BEGREP & EKSEMPEL & BEGREP & EKSEMPEL \\
\hline SETNING & $\begin{array}{c}\text { Jeg vil gjerne } \\
\text { slappe av hvis vi } \\
\text { har tid. } \\
\text { Hun liker å danse, } \\
\text { og han hater det. } \\
\text { Kom hit! } \\
\text { Er det deg? }\end{array}$ & ZDANIE & $\begin{array}{c}\text { Chciałabym } \\
\text { odpocząć, jeśli } \\
\text { mamy czas. } \\
\text { Ona lubi tańczyć, a } \\
\text { on tego nienawidzi. } \\
\text { Przyjdź tu! } \\
\text { Czy to (jesteś) ty? }\end{array}$ \\
\hline HELSETNING & $\begin{array}{c}\text { Jeg vil gjerne } \\
\text { slappe av hvis vi } \\
\text { har tid. } \\
\text { Hun liker å danse, } \\
\text { og han hater det. } \\
\text { Kom hit! } \\
\text { Er det deg? }\end{array}$ & ZDANIE & $\begin{array}{c}\text { Chciałabym } \\
\text { odpocząć, jeśli } \\
\text { mamy czas. } \\
\text { Ona lubi tańczyć, a } \\
\text { on tego nienawidzi. } \\
\text { Przyjdź tu! } \\
\text { Czy to (jesteś) ty? }\end{array}$ \\
\hline HOVEDSETNING & $\begin{array}{c}\text { Jeg vil gjerne } \\
\text { slappe av. } \\
\text { Hun liker å danse. } \\
\text { Og han hater det. }\end{array}$ & $\begin{array}{c}\text { ZDANIE } \\
\text { WSPÓŁRZĘDNE, } \\
\text { NIEZALEŻNE } \\
\text { ZDANIE }\end{array}$ & $\begin{array}{c}\text { Chciałabym } \\
\text { odpocząć. } \\
\text { Ona lubi tańczyć. } \\
\text { A on tego } \\
\text { nienawidzi. }\end{array}$ \\
\hline
\end{tabular}

${ }^{17}$ Før Norsk referansegrammatikk ble utgitt i 1997, anvendte man i norsk lingvistikk «den tradisjonelle ordklasseinndelingen» der konjunksjoner og subjunksjoner tilhørte én ordklasse konjunksjoner (Kulbrandstad 2005:108-109). 


\begin{tabular}{cccc}
\hline & $\begin{array}{c}\text { Kom hit! } \\
\text { Er det deg? }\end{array}$ & & $\begin{array}{c}\text { Przyjdź tu! } \\
\text { Czy to (jesteś) ty? }\end{array}$ \\
\hline OVERSETNING & $\begin{array}{c}\text { Jeg vil gjerne } \\
\text { slappe av (..). }\end{array}$ & $\begin{array}{c}\text { ZDANIE } \\
\text { NADRZĘDNE }\end{array}$ & $\begin{array}{c}\text { Chciałabym } \\
\text { odpocząć (...). }\end{array}$ \\
\hline LEDDSETNING & $(\ldots)$ hvis vi har tid. & $\begin{array}{c}\text { ZDANIE } \\
\text { PODRZĘDNE }\end{array}$ & $\begin{array}{c}(\ldots), \text { jeśli mamy } \\
\text { czas. }\end{array}$ \\
\hline LEDD-DELSETNING & $\begin{array}{c}\text { Utestedet vi skal } \\
\text { møtes på, er en bar } \\
\text { som heter Fru }\end{array}$ & $\begin{array}{c}\text { PODRZĘDNE } \\
\text { ZDANIE SKLADOWE }\end{array}$ & $\begin{array}{c}\text { Knajpa, w której } \\
\text { się spotykamy, to } \\
\text { bar, który nazywa } \\
\text { się Fru Haugans. }\end{array}$ \\
\hline
\end{tabular}

(Tabell 12) Sammenligning av setningsbegrepene i norsk og polsk.

En annen ulikhet $\mathrm{i}$ de norske og polske beskrivelsene av setninger er begrepsnavn man bruker i klassifiseringen av leddsetninger. I norsk er det vanlig å skrive om nominale, adjektiviske (men også relative) og adverbiale setninger (Golden mfl. 2014, Hagen 2008), mens det i den polske grammatikktradisjonen er vanlig å omtale setninger som intensjonale, relative og adverbiale. Det at det i grunnen dreier seg om de samme fenomenene, viser Tabell 13.

\begin{tabular}{|c|c|c|}
\hline TYPE LEDDSETNING & NORSK EKSEMPEL & POLSK EKSEMPEL \\
\hline NOMINAL / INTENSJONAL & $\begin{array}{c}\text { Jeg vet at vi oppnår } \\
\underline{\text { suksess. }}\end{array}$ & $\begin{array}{l}\text { Wiem, } \\
\underline{\text { że odniesiemy }} \\
\underline{\text { sukces. }}\end{array}$ \\
\hline ADJEKTIVISK / RELATIV & De som sitter der, er & $\mathrm{Ci}, \frac{\text { którzy tam siedzạ, }}{\text { Hiszą }}$ \\
\hline ADVERBIAL & $\begin{array}{l}\text { Jeg skal på kino selv om } \\
\text { jeg har dårlig tid. }\end{array}$ & $\begin{array}{l}\text { Idę do kina, } \underline{\text { mimo że }} \\
\underline{\text { niezbyt mam czas. }}\end{array}$ \\
\hline
\end{tabular}

(Tabell 13) Typer leddsetninger i norsk og polsk

Det er dessuten en nyanseforskjell i relativsetninger. Mens de i norsk deles videre inn i to grupper: restriktive og appositive, finnes det i polsk en tredje type i tillegg - utviklende (tilsynelatende relative) setninger som ikke nevnes i norske grammatikker hvor de trolig blir regnet som vanlige relativsetninger uten noen forbehold. Denne konklusjonen trekker vi ettersom ingen av de norske grammatikerne (bl.a. Faarlund mfl. 1997, Hagen 2008, Lie 2003) nevner denne typen relativsetninger.

En annen sak er selve forklaringene av begrepene og de lingvistiske forholdene. Det kan være mulig at vi som nordister ikke er helt objektive, men vi 
synes at mens den norske inndelingen presenteres på en klar og forståelig måte, er den polske mer innviklet og vanskelig å gjennomgå. En ting som derimot er felles $\mathrm{i}$ disse beskrivelsene, er at man kombinerer en strukturorientert tilnærming, med en mer semantisk og pragmatisk en. Dette gjennomføres imidlertid på ulike måter.

Vi vil til slutt nevne den siste, og kanskje den største forskjellen i setningsbeskrivelsene i norsk og polsk. Leddstilling i hel- og leddsetninger utgjør størsteparten av de norske syntaksomtalene. I polsk er det derimot et lite omtalt tema som problematiseres i bare noen få bøker. Det skyldes at norsk er et språk med fast ordstilling, mens polsk er kjent for å tillate mer frihet $\mathrm{i}$ ordstillingen ettersom leddets funksjon først og fremst markeres av kasus og ikke av dets posisjon i setningen.

\section{OPPSUMMERING}

Tanken bak denne artikkelen var å presentere og sammenlikne måten setninger i norsk og polsk klassifiseres på. Vi føler at det mangler en nyere systematisk oversikt der de to systemene, det norske og polske, omtales parallelt. Språktypologien tatt i betraktning ligger norsk og polsk langt fra hverandre. Likevel er setningen fortsatt et fenomen som defineres noenlunde likt $\mathrm{i}$ begge språkene. Måten setninger klassifiseres og inndeles på i begge språkene, virker imidlertid litt annerledes. Det viser seg nemlig at et gjennomgående trekk i den norske grammatikktradisjonen er å konsentrere seg heller om setningsstrukturen, dvs. ordstilling, mens i de mest brukte polske oppslagsverkene er det betydelig mer fokus på setningens semantiske innhold og forhold setningen uttrykker. Dette gir relativt frie tøyler for norske grammatikkforskere, som til tyr til flere begreper enn polske innlærere er vant til fra formell undervisning i hjemlandet. I polsk er det nemlig mer enstemmighet mellom enkelte inndelinger, men selve klassifiseringene virker svært innviklet. Det kommer veldig tidlig til syne at dersom de to systemene settes parallelt, kan det ikke være snakk om et én-til-én-forhold, noe som avspeiles i begrepsbruken. Ettersom en del begreper ikke dukker opp i polske grammatikker, har vi foreslått noen betegnelser som vi mener kan tas $\mathrm{i}$ bruk når de to systemene sammenliknes. Dette kan være aktuelt i kontrastive studier, der man går inn dypere på mindre enheter som inngår i setningsstrukturen, dvs. setningsledd, analyserer plassering av dem eller konsentrerer seg om selve systematikken for å saumfare enkelte setningstyper. Vi mener at denne artikkelen også kan være til nytte for lærere i norsk som andrespråk der man har med polske innlærere å gjøre. Siden setningsproblematikken virker lite gjennomsiktig i norsk, grunnet en god del begreper en polsk innlærer blir eksponert for, tror vi at det kan bli mye enklere å bruke den foreslåtte systematiseringen, der de norske setningstypene føyes inn i det polske systemet. Vi har derfor satt sammen norske og polske begreper i en 
tabell, slik at de kan inspiseres parallelt, med tilsvarende begreper i begge språkene. På denne måten kan det bli lettere å begripe premissene hovedinndelingen bygger på. Listen vi presenterer kan tas i bruk dersom fenomenet analyseres $\mathrm{i}$ undervisningstimer, men også ved tagging av korpusmateriale der polske norskbrukere er med, eller i parallelle korpuser. Artikkelen systematiserer altså vanskelige norske begreper og gjør det lettere fordøyelig for en polsk innlærer. I tillegg kan oversikten være et nyttig verktøy for forskere som kan fokusere på visse analyser uten å streve seg gjennom den polske begrepsjungelen.

Det er imidlertid en god del ting som artikkelen ikke retter lyset mot. En av dem er for eksempel et bredere innsyn i sammensatte setninger som sådan, der man også analyserer forhold i setninger sammensatt ved hjelp av konjunksjoner og subjunksjoner. Det hadde vært interessant å se på struktur i polske og norske setninger, bruk av bindeord, måten de samme funksjonene uttrykkes i polsk. Her hadde det også vært spennende å se på grammatisk struktur i hoved- og leddsetninger, siden den påvirkes i norsk i meget stor grad, mens i polsk virker bindeord å være uten større betydning for plassering av enkelte ledd. Selve betydningsinnholdet og måten et bindeord organiserer setningen på, er også verdt en nærmere inspeksjon. Det kan godt hende at tross tilsynelatende mange likheter, klarer man å kartlegge noen systematiske avvik mellom begge systemene som igjen kan bidra til en bedre forståelse av hvordan setningene konstrueres i de respektive språkene. Denne artikkelen tilbyr altså relativt grundig gjennomgang av systematikken som forhåpentligvis åpner for flere forskningsmuligheter på dette feltet.

\section{LITTERATUR}

Bauer, J., Grepl, M. (1970). Skladba spisovné češtiny. Praha: Státní pedagogické nakladatelství. Bąk, P. (2016). Gramatyka języka polskiego. Warszawa: Wiedza Powszechna.

Bhat, D.N.S. (1999). The Prominence of Tense, Aspect and Mood. Amsterdam/ Philadelphia: John Benjamins Publishing Company.

Daneš, F. (et al.). (1987). Mluvnice češtiny 3. Praha: Academia.

Enger, H.O., Kristoffersen, K.E. (2000). Innføring $i$ norsk grammatikk, morfologi og syntaks. Oslo: Cappelen Akademisk Forlag.

Faarlund, J.T. (et al.). (1997). Norsk referansegrammatikk. Oslo: Universitetsforlaget.

Golden, A. (et al.). (2014). Norsk som fremmedspråk. Grammatikk. Oslo: Universitetsforlaget.

Grzegorczykowa, R. (2008). Wyktady z polskiej składni. Warszawa: Wydawnictwo Naukowe PWN.

Hagen, J.E. (2008). Norsk grammatikk for andrespråkslcerere. 5 edition. Oslo: Ad Notam Gyldendal. Hagen, J.E. (1998). Norsk grammatikk for andrespråkslcerere. 1 edition. Oslo: Ad Notam Gyldendal. Janik, M.O. (2014). En kontrastiv analyse av norske og polske fortidstempora i et andrespråksperspektiv. NOA - Norsk som andrespråk 30, 106-131.

Klemensiewicz, Z. L. (1963). Zarys sktadni polskiej. Warszawa: Państwowe Wydawnictwo Naukowe. 
Kulbrandstad, L.A. (2005). Språkets mønstre. Grammatiske begreper og metoder. Oslo: Universitetsforlaget.

Lie, S. (2003). Innføring i norsk syntaks. 5 edition. Oslo: Universitetsfrolaget.

Mac Donald, K. (1999). Norsk grammatikk for fremmedspråklige. Oslo: J.W. Cappelens Forlag.

Markowski, A. (2004). Wielki stownik poprawnej polszczyzny. Warszawa: PWN.

Mędak, S. (2016). Praktyczny stownik tączliwości składniowej czasowników polskich, Kraków: Towarzystwo Autorów i Wydawców Prac Naukowych UNIVERSITAS.

Pisarek, W. (1964). O języku stowarzyszonym. Język polski 44. Kraków: Wydawnictwo Miłośników Języka Polskiego.

Polański K. (1978). Zdanie złożone. In: S. Urbańczyk (ed.) Encyklopedia wiedzy o języku polskim. Wrocław: Zakład Narodowy imienia Ossolińskich.

Polański K. (1967). Składnia zdania złożonego w języku górnołużyckim. Wrocław-WarszawaKraków: Komitet Słowianoznawstwa PAN.

Przybycin, A. (1976). Szyk wypowiedzeń podrzędnych w wypowiedzeniu złożonym niewspótrzędnie. Katowice: Prace naukowe Uniwersytetu Śląskiego.

Skommer, G. (1979). Leddsetninger i norsk og polsk - en konfrontativ analyse. Unpublished master's thesis. Poznań: Adam Mickiewicz Universitet.

Vassenden, L. (1993). Norsk syntaks. Oslo: Ad Notam Gyldendal.

Vinje, F.E. (1999). Riktig norsk. 5 edition. Oslo: Cappelen Akademisk Forlag.

Wróbel H. (2001): Gramatyka języka polskiego. Podręcznik akademicki. Kraków: Spółka Wydawnicza „OD NOWA” s.c.

Åfarli, T. A., Sakshaug, L. (2006). Grammatikk: Syntaks og morfologi med norsk i sentrum. Oslo: Det Norske Samlaget.

\section{Marta Olga Janik}

SWPS University of Social Sciences and Humanities

ul. Chodakowska 19/31

03-815 Warszawa

Poland

mjanik@swps.edu.pl

\section{Oliwia Szymańska}

Universitetet i Oslo

Postboks 1102

Blindern, 0313 OSLO

Norway

oliwia.szymanska@iln.uio.no

\section{Barbara Łukaszewicz}

University of Warsaw

ul. Igańska 32/31

04-083 Warszawa

Poland

barbara.lukaszewicz1@gmail.com 